\title{
Notes on the vocalizations of Common Wood-shrike (Tephrodornis pondicerianus)
}

\section{Peter Boesman}

In the following we briefly analyze and compare voice of the different races of Common Wood-shrike (Tephrodornis pondicerianus). We also try to quantify the extent of any vocal differences using the criteria proposed by Tobias et al. (2010), as a support for taxonomic review. We have made use of sound recordings available on-line from Xeno Canto (XC), Macaulay Library (ML) and Avian Vocalizations Center (AVoCet), and Warakagoda (2008).

Of main interest is race affinis of Sri Lanka. We have only located two recordings of this race. Apparently there are (at least) two different vocalizations:

A short series of slightly burry upslurred whistles with variable pace and note length:

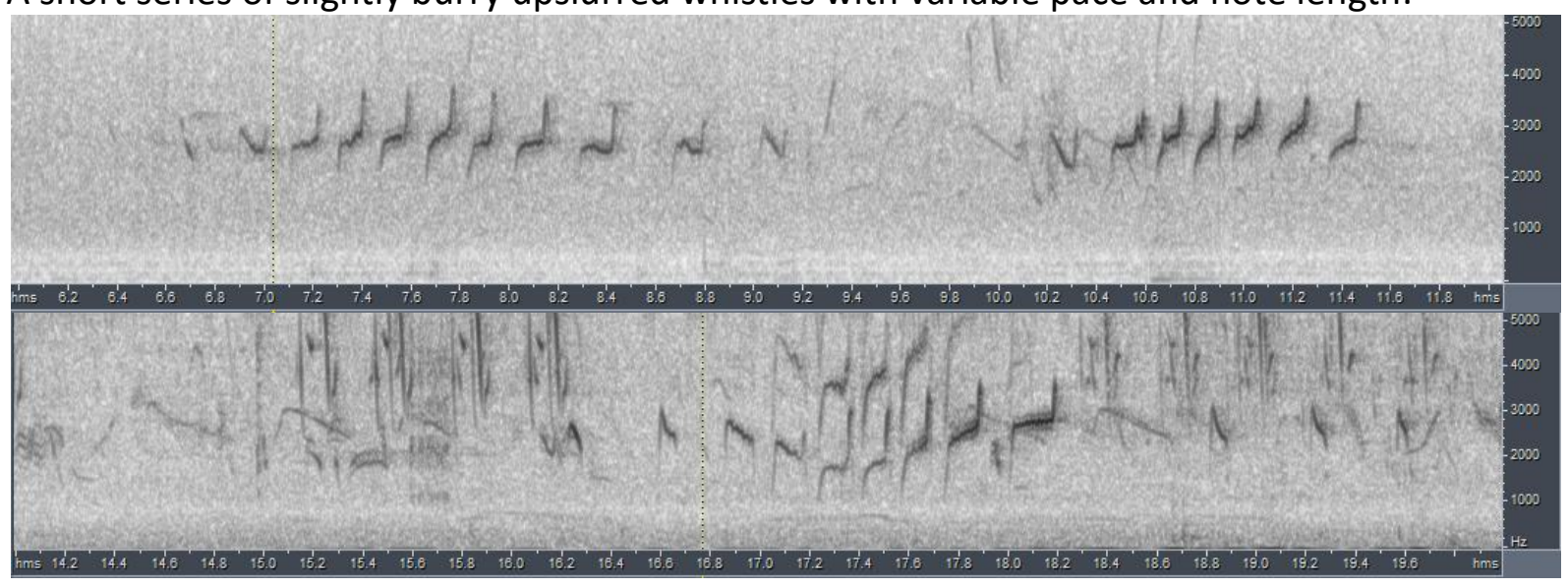

A longer series of upslurred whistles which are all rather constant:

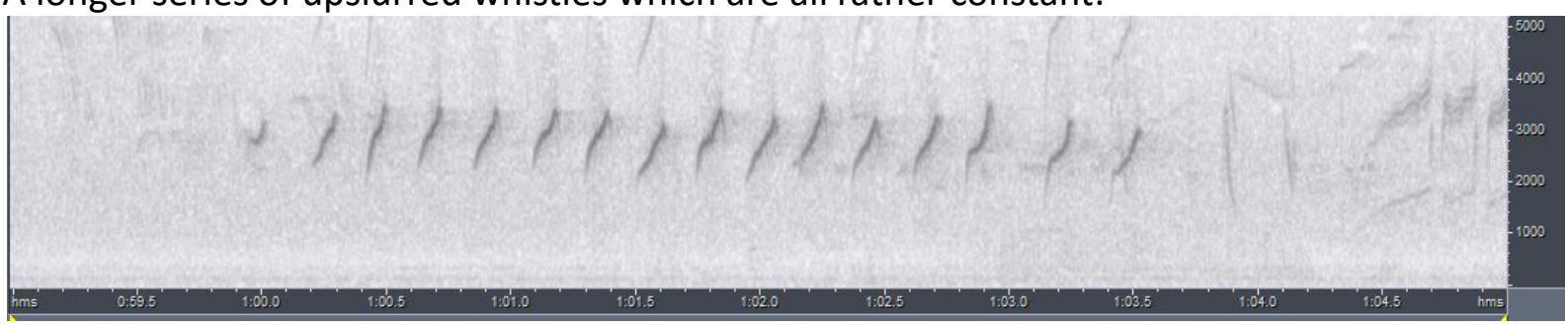

We compare these vocalizations with homologous vocalizations of the other races:

nominate

A short series of slightly burry upslurred whistles with variable pace and note length:

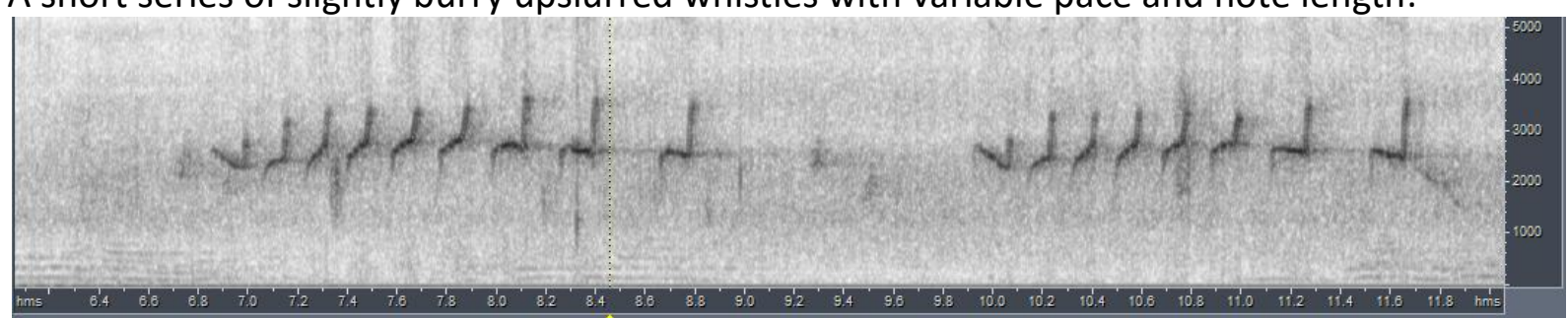




\section{HANDBOOK OF THE BIRDSPFGTHE WORLD The}

\section{ORNITHOLOGICAL NOTES}

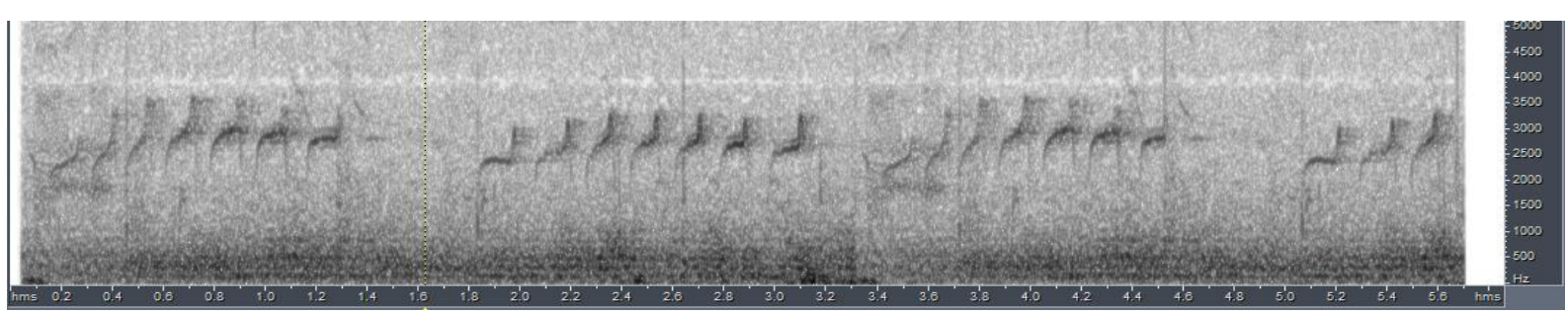

or a similar series of more burry notes:

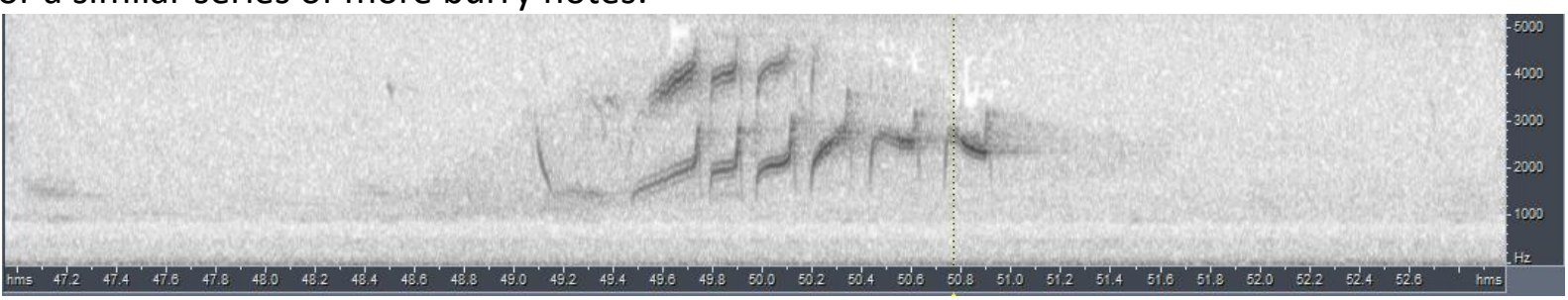

or a longer series:

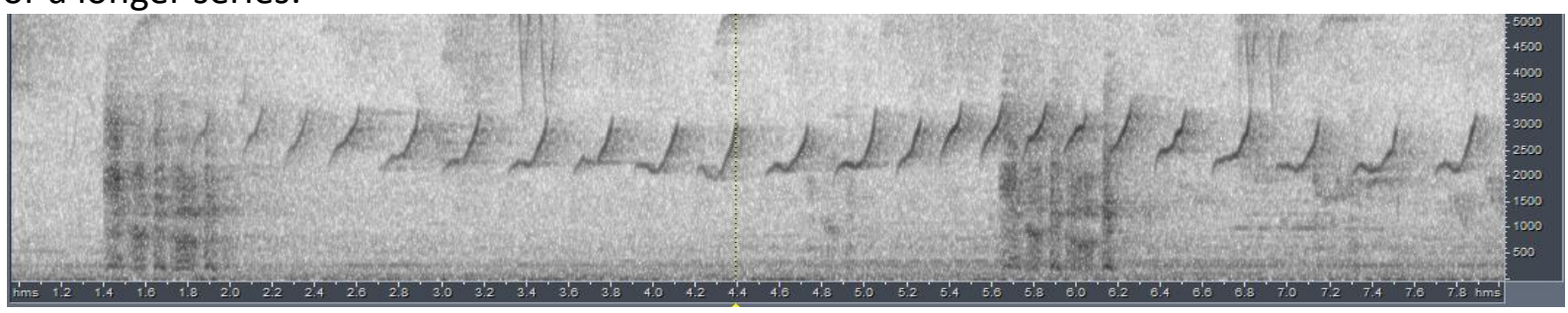

\section{race orientis}

A series of upslurred whistles:

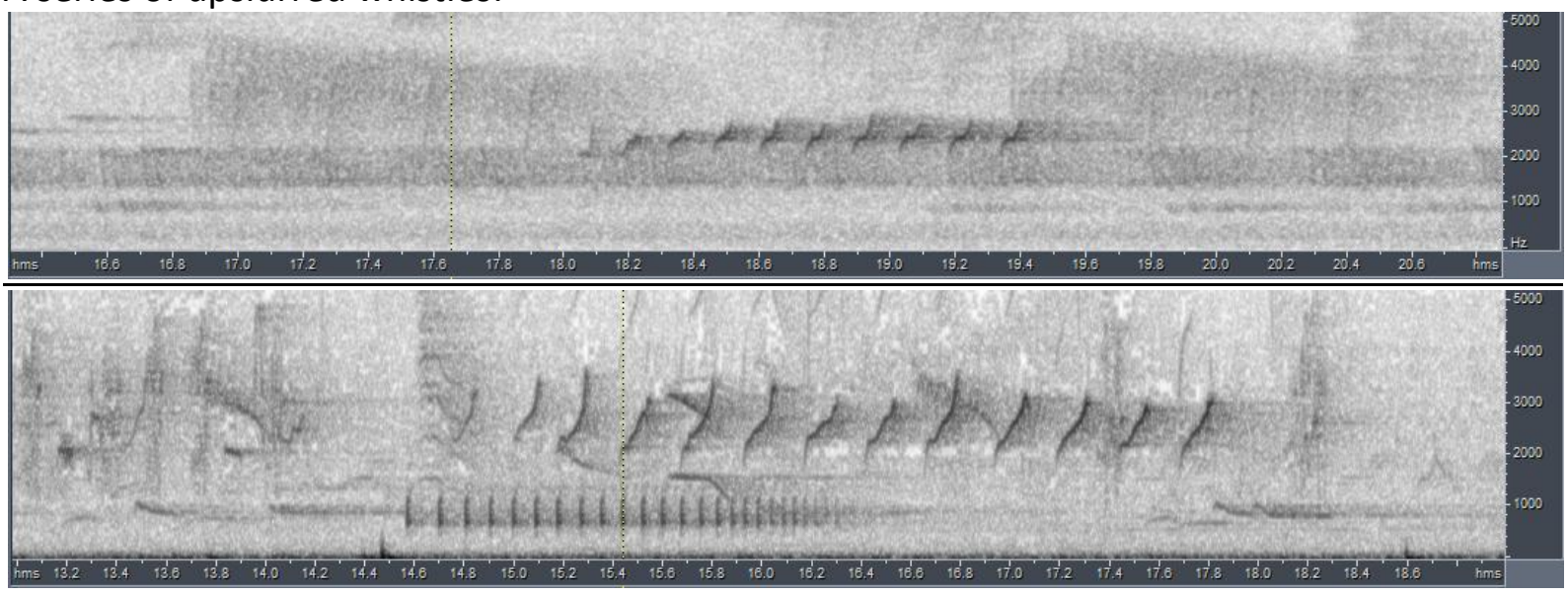

or a longer series:

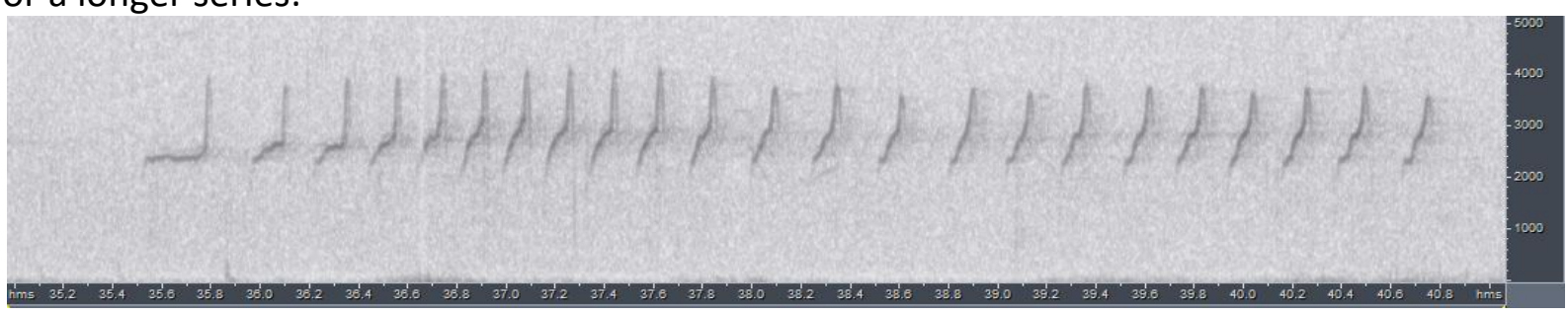

We couldn't locate homologous vocalizations of race pallidus (XC149695 of uncertain origin). 

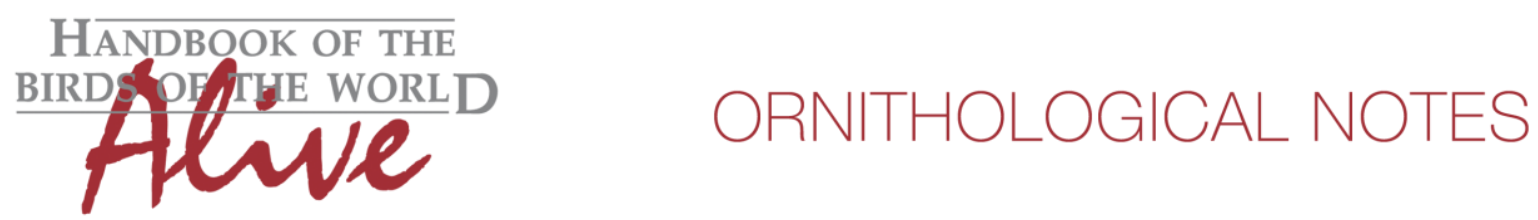

In Rasmussen et al. (2012), it is said: "Most vocalizations (of Ceylon Woodshrike) are similar to Common Woodshrike, but the main song-type differs strongly from any song-type of Common". This 'main song type' (according to the description) seemingly is the longer vocalization depicted above. nominate rarely makes such identical longer vocalizations, although the longer type depicted above comes very close. Furthermore, orientis also has such longer vocalizations, which are very similar to affinis. Obviously, with so few recordings available of affinis, the relative frequency with which the different vocalizations are given can't be determined.

The shorter song type is probably not separable, although nominate more often starts with a rather hoarse burry note quality.

All in all, it would seem that the vocal differences of affinis are rather overrated. We would require a much larger set of recordings to find out if there are any consistent differences in the vocalizations of affinis compared to the other races.

This note was finalized on 17 th November 2015 , using sound recordings available on-line at that moment. We would like to thank in particular the sound recordists: Sarthak Awhad, Patrik Åberg, Pronoy Baidia, Sagar Chandane, David Edwards, David Farrow, Vir Joshi, Frank Lambert, Linda Macaulay, Mike Nelson, Ramit Singal and Deepal Warakagoda.

\section{References}

Rasmussen, P.C. \& Anderton, J.C. (2012). Birds of South Asia: the Ripley Guide. Lynx Edicions, Barcelona.

Tobias, J.A., Seddon, N., Spottiswoode, C.N., Pilgrim, J.D., Fishpool, L.D.C. \& Collar, N.J. (2010). Quantitative criteria for species delimitation. Ibis 152(4): 724-746.

Warakagoda, D., Hettige, U. (2008). Birds of Sri Lanka: MP3 sound and image collection. Birdsounds.nl. Westernieland.

\section{Recommended citation}

Boesman, P. (2016). Notes on the vocalizations of Common Wood-shrike (Tephrodornis pondicerianus). HBW Alive Ornithological Note 184. In: Handbook of the Birds of the World Alive. Lynx Edicions, Barcelona. (retrieved from http://www.hbw.com/node/932122 on 25 August 2016). 